\title{
Localization of Glucose Oxidase with Immunocytochemistry in the Biocontrol Fungus Talaromyces flavus
}

\author{
S. K. Stosz, S. Roy, C. Murphy, W. Wergin, and D. R. Fravel
}

First and fifth authors: Biocontrol of Plant Diseases Laboratory; and second, third, and fourth authors: Nematology Laboratory, USDA-ARS, Beltsville, MD 20705.

Accepted for publication 17 March 1998.

\begin{abstract}
Stosz, S. K., Roy, S., Murphy, C., Wergin, W., and Fravel, D. R. 1998. Localization of glucose oxidase with immunocytochemistry in the biocontrol fungus Talaromyces flavus. Phytopathology 88:576-581.

Production of the enzyme glucose oxidase has been shown to be involved in the biological control of Verticillium wilt by Talaromyces flavus. In this study, the location of glucose oxidase was determined in $T$. flavus by immunocytochemistry using glucose oxidase-specific poly-

intracellular and extracellular. Old, as well as young, hyphal cells contained glucose oxidase, but labeling of the cell wall-associated enzyme decreased as the cells aged. Exocytosis rather than cell lysis was the primary means of release of glucose oxidase from cells. Enzyme stability studies confirmed that the glucose oxidase of T. flavus is an extremely stable enzyme, retaining $13 \%$ of its original activity after 2 weeks at $25^{\circ} \mathrm{C}$ and retaining activity for several days at temperatures up to $50^{\circ} \mathrm{C}$.
\end{abstract} clonal antibody. Immunostaining revealed that glucose oxidase was both

Glucose oxidases are glycoproteins that catalyze the oxidation of $\beta$-D-glucose to gluconic acid and hydrogen peroxide; molecular oxygen is consumed in the process. The glucose oxidase of the fungus Talaromyces flavus (Klöcker) Stolk and Samson (anamorph: Penicillium dangeardii Pitt) consists of two identical subunits of approximately $71 \mathrm{kDa}(10)$. The glucose oxidase from $T$. flavus is specific for D-glucose and has little or no residual activity with similar hexoses (9). In situ studies indicated that levels of hydrogen peroxide produced in the rhizosphere by the glucose oxidase of T. flavus were sufficient to retard growth of the wilt pathogen Verticillium dahliae (4). Subsequent studies confirmed that glucose oxidase from culture filtrates of $T$. flavus was solely responsible for the inhibition of $V$. dahliae microsclerotial germination in vitro (20).

In spite of the important function of this enzyme in biocontrol, very little is known about the cellular location of glucose oxidase in $T$. flavus or in other glucose oxidase-producing fungi such as Aspergillus and Penicillium spp. Reports on glucose oxidase localization are ambiguous or contradictory. For example, the glucose oxidase of $A$. niger has been reported in intracellular peroxisomes (23), as extracellular (14), or as intracellular prior to fungal autolysis (24). Much of this ambiguity may arise from differences in culturing conditions or from the age of the fungal cultures, because these parameters may have a significant effect on whether autolysis occurs and on the location of the enzyme. Furthermore, little is known about the mechanisms of glucose oxidase export. Zetelaki (24) associated export with autolysis of the fungus, whereas Mischak and coworkers (14) reported that the glucose oxidase of $A$. niger was excreted after syntheses. However, some enzyme remained associated with the cell wall mucilage and some enzyme found its way into the medium (14). The amount of cellassociated versus cell-free enzyme was a function of how much

Corresponding author: D. R. Fravel; E-mail address: dfravel@asrr.arsusda.gov

Publication no. P-1998-0420-02R

This article is in the public domain and not copyrightable. It may be freely reprinted with customary crediting of the source. The American Phytopathological Society, 1998.
Additional keywords: Verticillium dahliae. mucilage was formed by the mycelium (14), which is also a function of growth conditions.

The current study was undertaken to visualize in situ glucose oxidase of T. flavus and the mechanism(s) that may be involved in the appearance of extracellular glucose oxidase. This information will increase our understanding about the relative contributions made by the cell-associated and cell-free glucose oxidase of $T$. flavus in controlling Verticillium wilt. Understanding this process will enable alteration of growth conditions and formulations to optimize production of cell-associated or cell-free glucose oxidase to optimize biocontrol by $T$. flavus.

\section{MATERIALS AND METHODS}

Fungal isolates and culture conditions. T. flavus isolate Tf-1 (13) was grown on a shaker $(125 \mathrm{rpm})$ in liquid medium containing $8.0 \%$ glucose $(\mathrm{T} 2)$ at $25^{\circ} \mathrm{C}(15)$. $\mathrm{T} 2$ medium $(100 \mathrm{ml})$ was inoculated with two 1.2-cm-diameter discs of T. flavus from 3-weekold plates of potato dextrose agar (Difco Laboratories, Detroit). For transmission electron microscope (TEM) studies, T. flavus was grown for 7 days at $125 \mathrm{rpm}$ in T2 medium at $25^{\circ} \mathrm{C}$. For glucose oxidase partitioning studies, cultures were destructively sampled for each of 7 days. Three replicates were sampled for each day, and the average glucose oxidase activity was recorded.

Enzyme preparations and assays. Culture filtrates were prepared by filtering $100 \mathrm{ml}$ of T. flavus grown in liquid T2 medium through a $0.45-\mu \mathrm{m}$ filter. Purified glucose oxidase from $T$. flavus was prepared as described previously (20) and stored at $-70^{\circ} \mathrm{C}$. Purified glucose oxidase from A. niger was purchased from Sigma (Sigma Chemical Co., St. Louis). Glucose oxidase activity was determined spectrophotometrically at $25^{\circ} \mathrm{C}$ and reported in units, in which 1 unit oxidizes $1.0 \mu \mathrm{mol}$ of $\beta$-D-glucose per min to gluconic acid and hydrogen peroxide at $25^{\circ} \mathrm{C}(2)$.

Antibody production. Polyclonal antibody specific for the glucose oxidase of $T$. flavus (pABGO-1) was developed and characterized as described previously (20).

Preparation of specimens for electron microscopy. For ultrastructural studies, small portions of fungal biomass obtained by filtering were fixed in $3.0 \%$ glutaraldehyde (vol/vol; Electron 
Microscopy Science, Fort Washington, PA) overnight in $0.05 \mathrm{M}$ phosphate buffer, $\mathrm{pH}$ 6.8, and then washed six times in additional phosphate buffer. Samples were postfixed in $2.0 \%$ osmium tetroxide (vol/vol; Electron Microscopy Science) in phosphate buffer for $2 \mathrm{~h}$. After dehydration in an alcohol series, the samples were embedded in Spurr's epoxy resin (Ted Pella Inc., Redding, CA) as described by Roland and Vian (16). For immunolabeling studies, samples were fixed for $2 \mathrm{~h}$ in $4 \%$ paraformaldehyde- $2.0 \%$ glutaraldehyde (Electron Microscopy Science) in $0.2 \mathrm{M}$ phosphate buffer, $\mathrm{pH} 7.4$ ( $\mathrm{vol} / \mathrm{vol} / \mathrm{vol})$, and then washed in the same buffer. After dehydration in an alcohol series, samples were embedded in LR white methacrylate resin (Ted Pella Inc.) (16).

Immunofluorescence labeling. Semithin sections $(0.5 \mu \mathrm{m})$ that were mounted on multiwell glass slides were incubated for $30 \mathrm{~min}$ in normal goat serum diluted 1:30 (vol/vol) in $0.5 \mathrm{M}$ Tris-buffered saline (TBS), $\mathrm{pH} 7.4$, containing $0.5 \%$ bovine serum albumin (BSA). Sections were treated overnight at $4^{\circ} \mathrm{C}$ with the antiserum to glucose oxidase, pABGO-1, diluted 1:400 in TBS plus BSA. Specimens were thoroughly rinsed in TBS. Sections were then treated for $1 \mathrm{~h}$ in the dark with goat anti-rabbit immunoglobulin labeled with fluorescein isothiocyanate (FITC) (Vector Laboratories, Inc., Burlingame, CA), and then thoroughly rinsed in TBS and in sterile distilled water. Control staining was performed identically, except that the incubating medium contained pABGO-1 preincubated with purified glucose oxidase from A. niger (Sigma Chemical Co.) at a concentration of $5 \mathrm{mg} / \mathrm{ml}$. A nonlabeled section was also observed in parallel to the control for autofluorescence. Observations were made with a Zeiss epifluorescence microscope (Carl Zeiss Inc., Thornwood, NY) equipped with a 485-nm excitation filter and a 515- to 565-nm barrier filter.

Immunogold labeling. Ultrathin sections $(75 \mathrm{~nm})$ were collected on gold grids and incubated for $30 \mathrm{~min}$ in normal goat serum diluted 1:30 (vol/vol) in 0.05 M TBS containing 0.5\% BSA. The sections were treated overnight at $4^{\circ} \mathrm{C}$ with pABGO-1 diluted 1:400 in TBS, and then the grids were rinsed three times in TBS. Sections were treated for $1 \mathrm{~h}$ with $10 \mathrm{~nm}$ of colloidal gold goat anti-rabbit immunoglobulin complex (IgG) (BioCell Research Laboratories, Cardiff, United Kingdom) diluted 1:30 in TBS. Specimens were then rinsed thoroughly in TBS followed by sterile distilled water. Several control experiments were performed in order to assess the specificity of the labeling: (i) replacement of the primary antibody with preimmune serum; (ii) preincubation of the primary antibody with glucose-oxidase from A. niger at a concentration of $5 \mathrm{mg}$ of enzyme per $\mathrm{ml}$; or (iii) omission of the primary antibody. Sections were stained in uranyl acetate for $20 \mathrm{~min}$ and observed with a $\mathrm{H}-500 \mathrm{H}$ transmission electron microscope (Hitachi Scientific Instruments, Mountain View, CA) operating at $75 \mathrm{kV}$.

Enzyme deglycosylation. Partially purified glucose oxidase from T. flavus was digested with $N$-glycosidase F (Boehringer Mannheim, Indianapolis, IN). Samples were separated by $10 \%$ sodium dodecyl sulfate polyacrylamide gel electrophoresis (SDS-PAGE) (12) and silver-stained for total protein as well as immunostained with pABGO-1 (18,22).

Enzyme partitioning studies. T. flavus was grown in $100 \mathrm{ml}$ of liquid $\mathrm{T} 2$ medium at $25^{\circ} \mathrm{C}$. Three flasks were destructively sampled daily for 7 days by vacuum filtration through a $0.45-\mu \mathrm{m}$ filter. The filtrate was assayed for glucose oxidase activity by a spectrophotometric assay, and the biomass was washed with $100 \mathrm{ml}$ of sterile distilled water and filtered again. The washed biomass was resuspended in $40 \mathrm{ml}$ of sterile distilled water and ground thoroughly in a Tenbroeck-type, 15-ml Pyrex tissue grinder (Thomas Scientific, Swedesboro, NJ). This preparation was centrifuged at $5,000 \times g$ for $15 \mathrm{~min}$ and the supernatant assayed for glucose oxidase activity by the method described previously $(10,11)$. All glucose oxidase activity detected from the crushed biomass was considered to be hyphal cell-associated, recog- nizing that this may include extracellular enzyme that is tightly bound to the cell wall.

Enzyme stability. $T$. flavus was grown for 5 days in liquid T2 medium as described above. The culture then was vacuum-filtered through a $0.45-\mu \mathrm{m}$ filter. Culture filtrates were held at temperatures of 20 to $55^{\circ} \mathrm{C}$ and enzyme activity determined spectrophotometrically. This experiment was repeated once, yielding similar results. Data from the two tests were averaged.
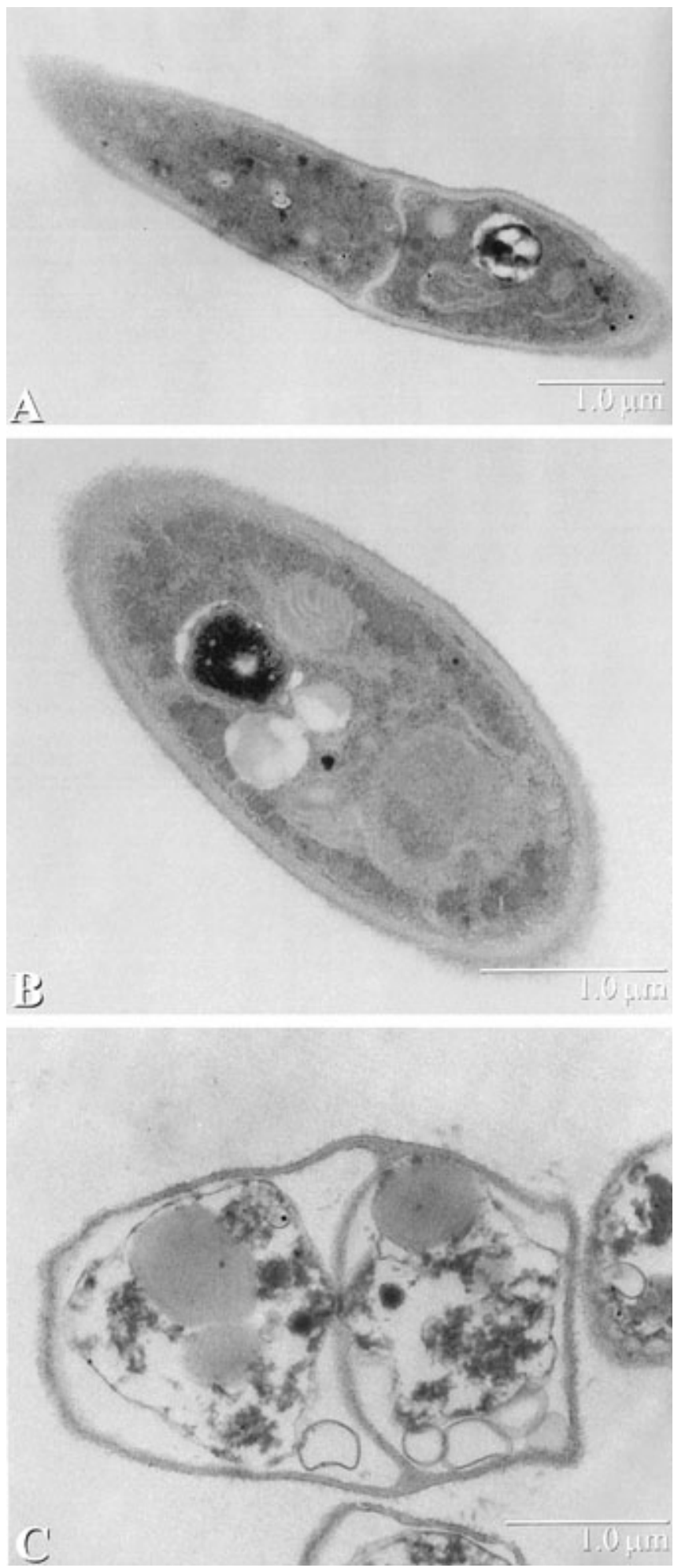

Fig. 1. Transmission electron micrographs of ultrathin sections of Talaromyces flavus. T. flavus was grown for 7 days on liquid T2 medium and the biomass embedded in Spurr's epoxy resin. A, Oblique section of young hypha; $\mathbf{B}$, transverse section of young hypha; and $\mathbf{C}$, old hypha. 


\section{RESULTS}

Ultrastructure. Longitudinal sections of young T. flavus hyphae (Fig. 1A) revealed a clearly defined septum with Woronin bodies visible on either side. The cytoplasm was densely packed with ribosomes. Transverse sections of young $T$. flavus hyphae (Fig. 1B) revealed a cortex of glycogen globules and a cytoplasm rich in ribosomes. Vesicles opening to join the cell wall were also observed in transverse sections. In contrast, old T. flavus hyphal cells were devoid of well-formed organelles, except for vacuoles and Woronin bodies. The cells exhibited plasmolysis and degeneration (Fig. 1C). The hyphal cell wall was intact, but was much thinner than in young hyphae. No evidence of cell activity was observed in older hyphae.

Immunogold labeling of T. flavus. Immunogold labeling of young $T$. flavus cells using antiserum specific for T. flavus glucose oxidase, pABGO-1, indicated the presence of glucose oxidase in cell walls of transverse (Fig. 2A) and longitudinal (Fig. 2B) sections throughout the hyphae. Gold-labeled glucose oxidase was also evident in clusters within vesicle-like structures in the cytoplasm (Fig. 2A and B). In several instances, membranes of vesicles were observed fusing with plasmalemmas (Fig. 2A and B); this indicates exocytosis. Old T. flavus cells (Fig. 2C) also contained glucose oxidase-specific label in their cell walls. However, fewer gold particles were seen within the cytoplasm of older cells than in younger cells. When preimmune serum was used (at $10 \times$ the concentration of immune serum) to label T. flavus, essentially no labeling was detected (Fig. 2D). Similarly, when the primary antibody was omitted, no labeling was observed (data not shown).

Immunofluorescence labeling of $\boldsymbol{T}$. flavus. When thin sections of T. flavus hyphae were stained with pABGO-1 and labeled with fluorescent-conjugated secondary antibody, glucose oxidase was seen uniformly distributed in the cell wall within the fungus population (Fig. 3). No fluorescence was observed when preinoculated
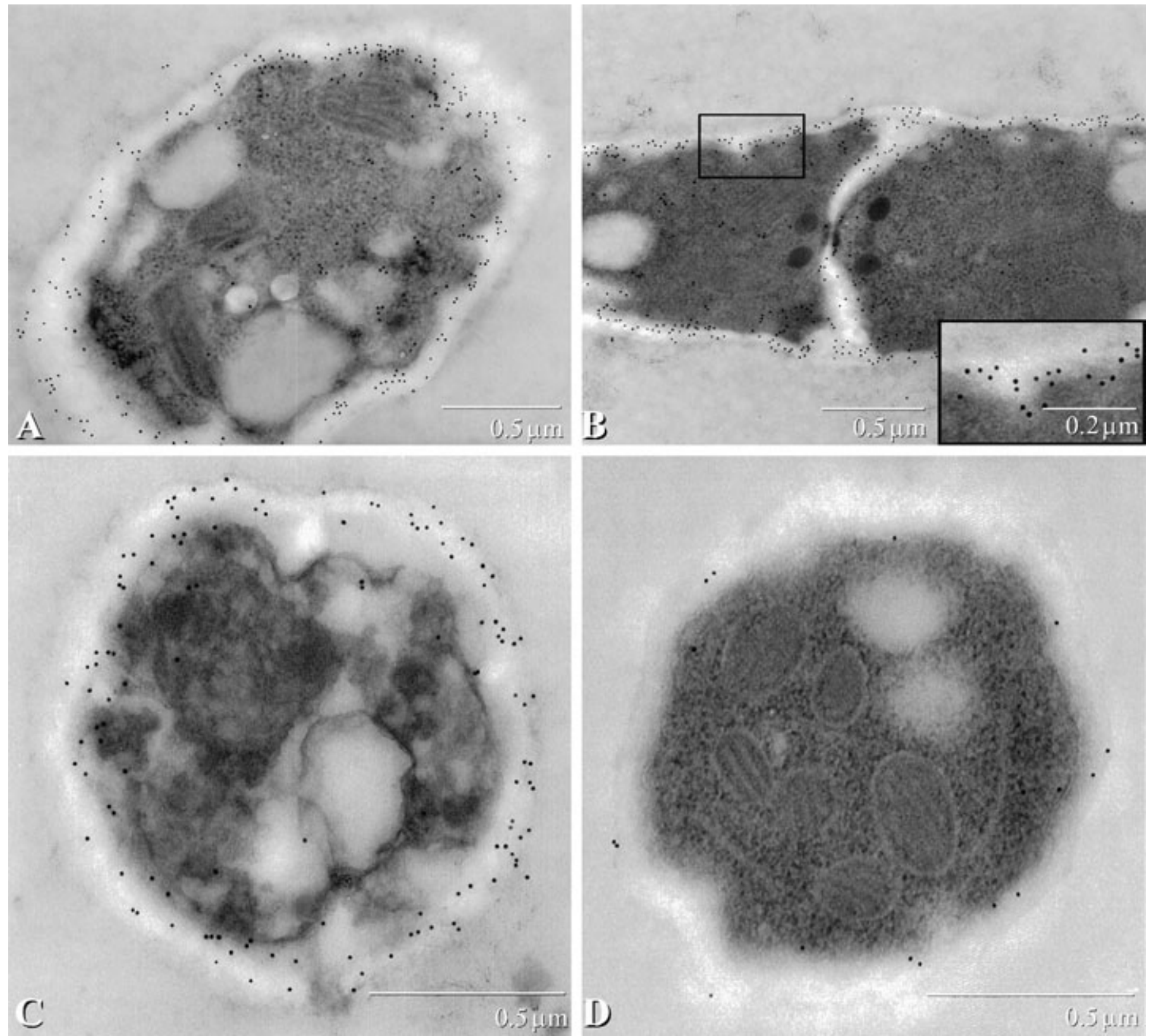

Fig. 2. Immunogold labeling of thin sections of Talaromyces flavus with glucose oxidase-specific antiserum pABGO-1. T. flavus was grown for 7 days in liquid T2 medium, embedded in LR white methacrylate, and immunostained. The secondary antibody was conjugated with 10-nm colloidal gold particles. A, Transverse section of young hypha; B, longitudinal section of young hypha; C, old hypha; and D, young hypha stained with preimmune serum (using 10X the concentration of that used for immune serum). Enlarged area shows glucose oxidase-containing vesicle joining with the cell wall. 
pABGO-1 with glucose oxidase from A. niger was used or when an unlabeled section was examined (data not shown).

Specificity of antiserum pABGO-1. The specificity of pABGO1 for glucose oxidase was established in several ways. In earlier studies, pABGO-1 did not react with culture filtrates of $T$. flavus grown in Neurospora minimal medium in which xylan was the sole carbon source (NMMX) $(1,19,20)$. Glucose oxidase production by $T$. flavus in NMMX is extremely low. However, T. flavus culture filtrates from cultures grown in T2, a glucose medium, contained high levels of glucose oxidase (20). T. flavus cultures grown in T2 medium did stain with pABGO-1, revealing one protein band of approximately $71 \mathrm{kDa}(20)$, the predicted molecular mass of glucose oxidase (10). Antiserum pABGO-1 also crossreacted with purified glucose oxidase from A. niger (Fig. 4).

Because glucose oxidase is a glycoprotein and because the cell walls of $T$. flavus were labeled with the glucose oxidase-specific antiserum pABGO-1, an attempt was made to determine whether this antiserum was specific for oligosaccharide moieties on the glucose oxidase and if it might cross-react with similar macromolecules on the cell walls of $T$. flavus. Purified glucose oxidase from $T$. flavus was digested with $\mathrm{N}$-glycosidase $\mathrm{F}$ and immunostained with pABGO-1. When compared with undigested glucose oxidase from $T$. flavus, the digested glucose oxidase was a smaller molecular weight, indicating that the protein had been deglycosylated (Fig. 5). Furthermore, the deglycosylated glucose oxidase still reacted with pABGO-1 as strongly as undigested glucose oxidase (Fig. 5), indicating that the antiserum pABGO-1 was specific for the protein portion of the glycoprotein molecule. When antiserum pABGO-1 was preabsorbed with glucose oxidase from $A$. niger, the amount of immunogold label detected in fungal cell walls was greatly reduced (Fig. 6B) compared with the untreated serum (Fig. 6A).

Partitioning of glucose oxidase activity. Immunogold labeling showed that a portion of the exported glucose oxidase remained associated with the fungal cell wall (Fig. 2A, B, and C). Data indicated that cell-associated glucose oxidase activity peaked 3 days after inoculation at $21.3 \%$. The amount of cell-associated enzyme declined through day 7 , at which time less than $9 \%$ of total glucose oxidase activity was cell associated (Fig. 7).

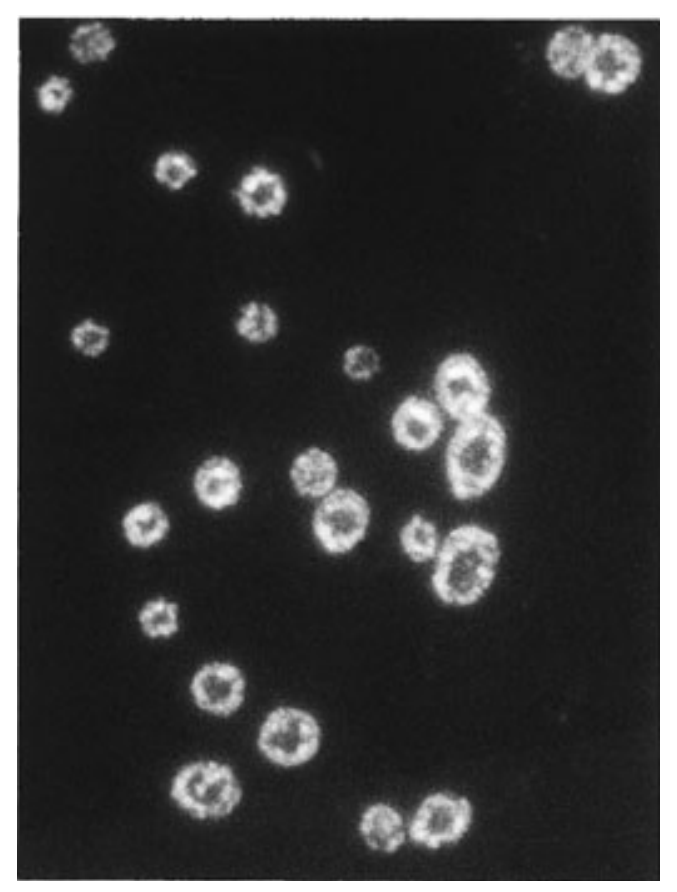

Fig. 3. Immunofluorescent labeling of semithin sections of Talaromyces flavus using glucose oxidase-specific antiserum, pABGO-1, reveals the uniform distribution of glucose oxidase in the fungal cell wall. $T$. flavus cultures were grown for 7 days in liquid T2 medium. Secondary antibody was conjugated with fluorescein isothiocyanate.
Enzyme stability. A substantial portion of the glucose oxidase produced remained associated with the $T$. flavus cells. Therefore, an attempt was made to determine the stability of glucose oxidase activity. Glucose oxidase activity in culture filtrates of $T$. flavus was extremely stable. Culture filtrates retained $13.2 \%$ of their original glucose oxidase activity after 14 days of incubation at

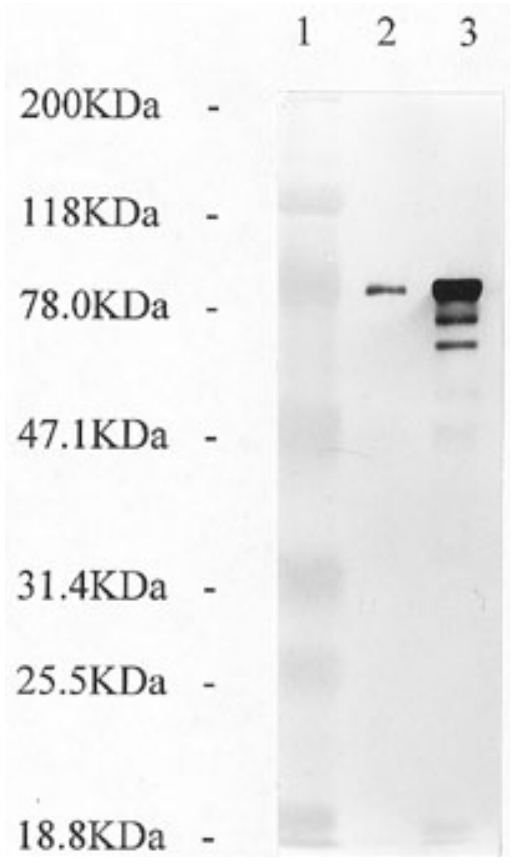

Fig. 4. Glucose oxidase separated by $7 \%$ sodium dodecyl sulfate-polyacrylamide gel electrophoresis and immunostained with antiserum, pABGO-1. Lane 1, Prestained molecular weight markers $(\mathrm{kDa})$; lane 2, purified glucose oxidase from Aspergillus niger $(2.5 \mu \mathrm{g})$; and lane 3 , partially purified glucose oxidase from Talaromyces flavus $(0.5 \mu \mathrm{g})$.

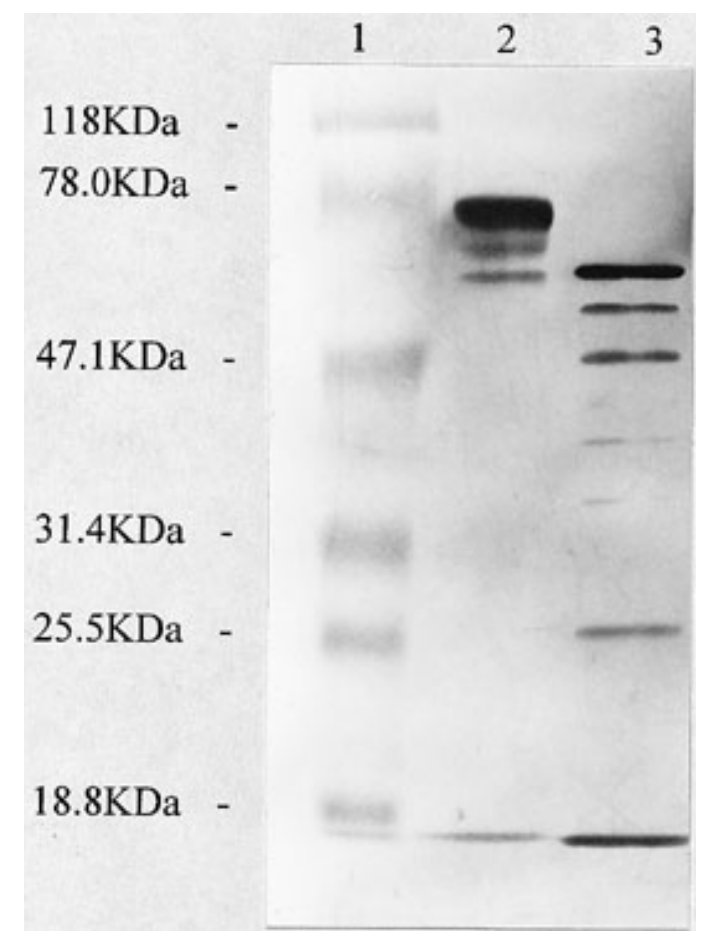

Fig. 5. Ten percent sodium dodecyl sulfate-polyacrylamide gel electrophoresis immunostained with glucose oxidase-specific polyclonal antiserum pABGO-1. Lane 1, Prestained molecular weight markers (kDa); lane 2, partially purified glucose oxidase from Talaromyces flavus; and lane 3, partially purified glucose oxidase from $T$. flavus treated with $\mathrm{N}$-glycosidase F. 
$25^{\circ} \mathrm{C}$ (Table 1). Glucose oxidase was also stable at elevated temperatures. After 5 days of incubation at 30,45 , or $50^{\circ} \mathrm{C}$, culture filtrates retained $41.0,44.0$, and $28.7 \%$ original glucose oxidase activity, respectively. After 9 days of incubation at 45 or $50^{\circ} \mathrm{C}$, culture filtrates retained 30.0 and $4.7 \%$ original glucose oxidase activity, respectively. At $55^{\circ} \mathrm{C}$, glucose oxidase activity was substantially less stable. After $24 \mathrm{~h}$ of incubation at $55^{\circ} \mathrm{C}$, glucose oxidase activity was detectable (Table 1).

\section{DISCUSSION}

The ultrastructural features observed in T. flavus are similar to those previously described in other fungi. A cell culture showed a
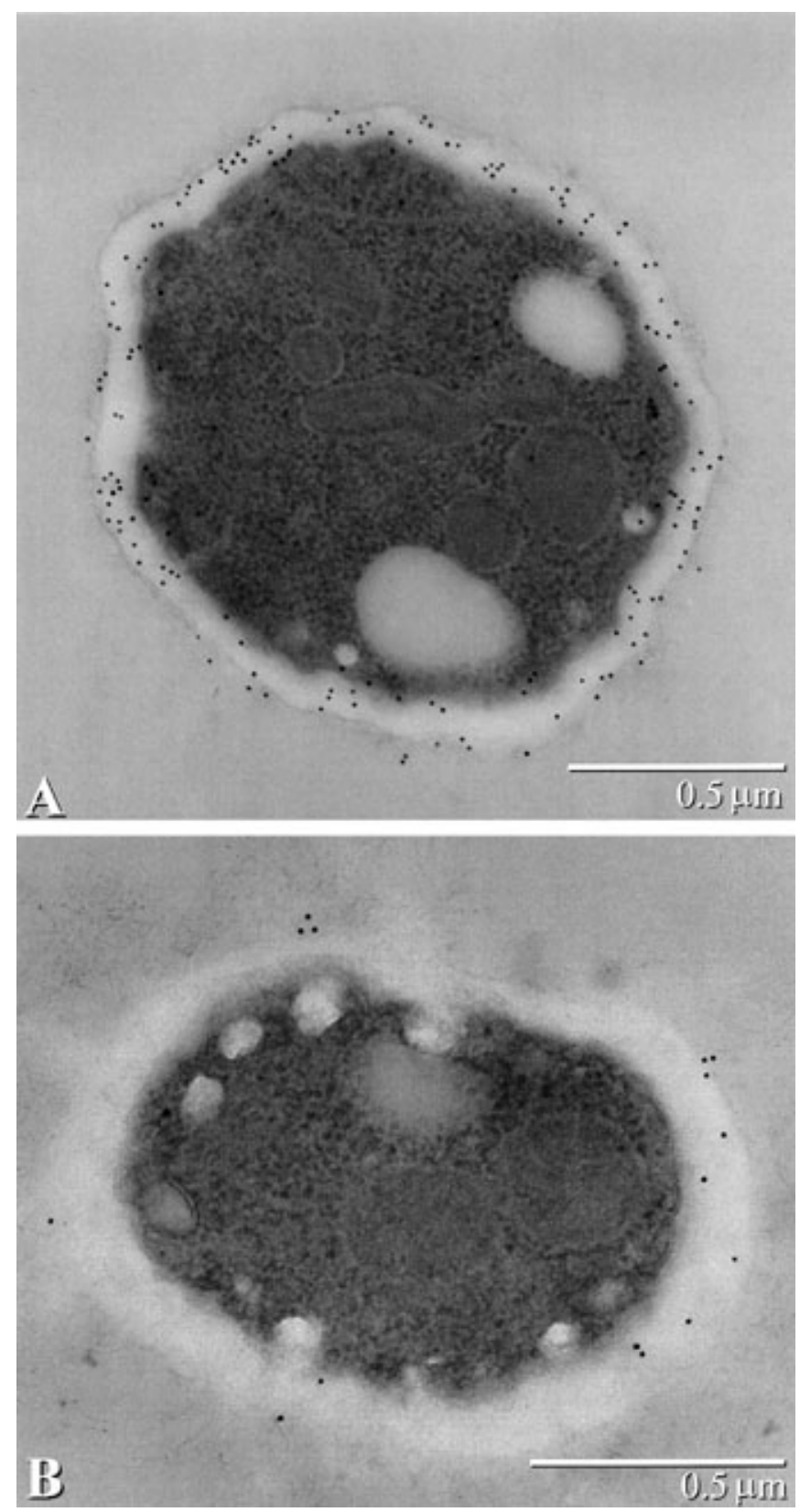

Fig. 6. Specificity of polyclonal antiserum pABGO-1 for glucose oxidase was determined by preincubating $\mathrm{pABGO}-1$ with purified glucose oxidase from Aspergillus niger. Thin sections of Talaromyces flavus biomass grown for 7 days in liquid T2 medium were embedded in LR white methacrylate and immunostained with either untreated pABGO-1 or preincubated pABGO-1. Secondary antibody conjugated to $10-\mathrm{nm}$ colloidal gold beads was used and the level of cell wall labeling compared. A, Untreated antiserum, pABGO-1; and $\mathbf{B}, \mathrm{pABGO}-1$ preincubated with purified glucose oxidase from A. niger. heterogeneous population of cells containing young and old cells. The percentage of these two different cell types depends on the age of the culture. The major differences between the young and old hyphae are in the thickness of the cell wall and the activity state of the cytoplasm. Old hyphae may have thinner cell walls, possibly due to decreased mucilage.

Several experiments were conducted that established the specificity of antiserum pABGO-1 for the protein portion of glucose oxidase. First, preimmune serum did not react with $T$. flavus tissue of any age. Second, when antiserum pABGO-1 was preabsorbed with purified glucose oxidase from $A$. niger, substantially less labeling occurred in the cell walls of T. flavus compared with nontreated pABGO-1. This result indicates that pABGO-1 is specific for the glucose oxidase, and the labeling represents in situ visualization of glucose oxidase in T. flavus. Third, glucose oxidase was treated with $\mathrm{N}$-glycosidase $\mathrm{F}$ to determine that the protein portion of the enzyme and not sugar side chains was reacting to pABGO-1. The deglycosilated protein reacted with pABGO-1, which indicated that the antiserum recognized protein and not sugar epitopes (Fig. 5). The presence of fainter, smaller molecular weight bands below the predominant deglycosylation product (Fig. 5) in Western blots probably result from incomplete deglycosilation or from heterogeneity in the carbohydrate component of the glucose oxidase of T. flavus (multiple bands are seen in digested and un-

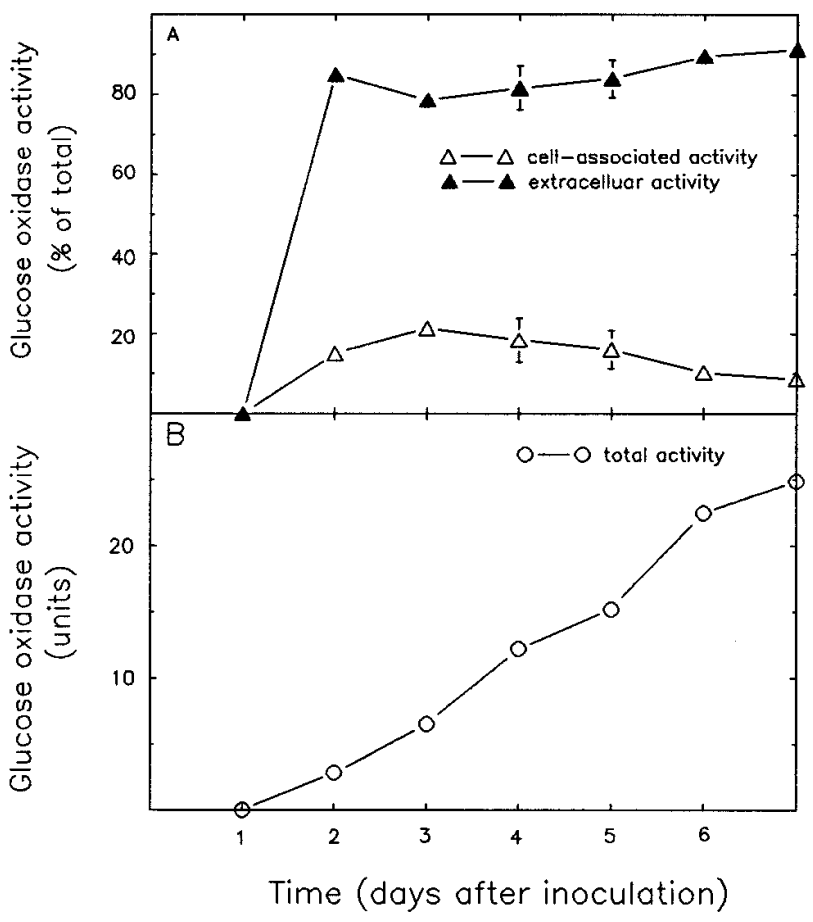

Fig. 7. Partitioning of glucose oxidase activity in Talaromyces flavus grown for 7 days in liquid T2 medium. A, Cell-associated and extracellular glucose oxidase activity as percent total activity; and $\mathbf{B}$, total glucose oxidase activity. In some cases, error bars are smaller than the symbols used as data points.

TABLE 1. Effect of length of storage at various temperatures on activity of glucose oxidase (\% of original) from Talaromyces flavus

\begin{tabular}{lcccccc}
\hline & \multicolumn{5}{c}{ Length of incubation (days) } \\
\cline { 2 - 7 } Temperature $\left({ }^{\circ} \mathrm{C}\right)$ & 1 & 5 & 6 & 9 & 13 & 14 \\
\hline 25 & 100 & 71.3 & 63.7 & $\mathrm{nd}^{\mathrm{a}}$ & 24.6 & 13.2 \\
30 & nd & 41.0 & nd & nd & nd & nd \\
45 & nd & 44.0 & nd & 30.0 & nd & nd \\
50 & nd & 28.7 & nd & 4.7 & nd & nd \\
55 & 4.3 & nd & nd & nd & nd & nd \\
\hline
\end{tabular}

${ }^{a}$ Not determined. 
digested enzyme) (Fig. 5). We concluded that pABGO-1 specifically recognizes the glucose oxidase of $T$. flavus.

When samples of T. flavus mycelium were immunogold-labeled using the glucose oxidase specific antibody pABGO-1, glucose oxidase was found associated with the cell wall. The presence of gold particles within vesicle-like structures in the cytoplasm of young cells and fusion of membranes of vesicles containing gold label with the plasmalemma suggest that secretion of glucose oxidase occurs. No clear evidence of active transport was observed in old cells. This indicates that cell lysis is not the mechanism by which glucose oxidase was transported. Instead, the enzyme is secreted in the cell wall while the cell is young and remains active.

Although TEM indicated that glucose oxidase was present in the cell walls of young and old hyphal cells, the percentage of the total glucose oxidase production in the cell wall was not determined with microscopy. Enzyme partitioning studies (Fig. 7) indicated that as much as $21.3 \%$ of the total glucose oxidase produced remained associated with the cell and that the amount of cell-associated enzyme decreased with the age of the culture. Although the primary function of this enzyme in T. flavus is likely to be nutritional, the enzyme is also known to function in antibiosis $(3,9)$. Further, there is glucose present at critical sites in the rhizosphere for sufficient hydrogen peroxide to be produced to inhibit V. dahliae (4).

Our observations indicated that glucose oxidase remained associated with older cells that were no longer metabolically active. While the antibody detected the presence, rather than the activity, of glucose oxidase, it is assumed that the enzyme is active due to its stability (Table 1). Assuming a source of glucose exists for the cell-bound enzyme, dead fungal tissue could continue to produce hydrogen peroxide and serve in an antibiotic capacity. Although glucose is scarce in soil, it may be found at root tips and junctions of lateral root emergence $(5,17)$, in exudates of T. flavus and the fungal cell wall $(6,7)$, or in material from the other microbiota resident in the soil. Sufficient quantities of glucose are available in soil to produce enough hydrogen peroxide to kill microsclerotia of $V$. dahliae (4). The enzyme's carbohydrate moieties may even serve as a source of glucose, since sugar chains of glucose oxidase from $A$. niger were found to be nonessential to enzyme activity $(8,21)$.

These data provide evidence that in young, active cells glucose oxidase is secreted within the cell wall. Once cells become nonviable, enzyme that may still be active is gradually released. Understanding the roles that cell-associated versus cell-free glucose oxidase play in the survival of T. flavus in soil and the role glucose oxidase plays in biocontrol of plant diseases will help to optimize conditions for glucose oxidase production for the most effective biocontrol.

\section{ACKNOWLEDGMENTS}

We thank C. Pooley for technical assistance.

\section{LITERATURE CITED}

1. Beadle, G. W. 1945. Genetics and metabolism in Neurospora. Physiol. Rev. 25:643-663.

2. Decker, L. A. 1977. Worthington Enzyme Manual. Worthington Biochemicals Corp., Freehold, NJ.

3. Fravel, D. R., Kim, K. K., and Papavizas, G. C. 1987. Viability of microsclerotia of Verticillium dahliae reduced by a metabolite produced by Talaromyces flavus. Phytopathology 77:616-619.

4. Fravel, D. R., and Roberts, D. P. 1991. In situ evidence for the role of glucose oxidase in the biocontrol of Verticillium wilt by Talaromyces flavus. Biocontrol Sci. Technol. 1:91-99.

5. Funck-Jensen, D., and Hockenhull, J. 1984. Root exudation, rhizosphere microorganisms and disease control. Växtskyddsnotiser 48:49-54.

6. Gomez-Miranda, B., Moya, A., and Leal, J. A. 1988. Differences in cell wall composition in the type species of Eupenicillium and Talaromyces. Exp. Mycol. 12:258-263.

7. Griffin, D. H. 1994. Fungal Physiology. 2nd ed. Wiley-Liss, New York.

8. Kalisz, H. M., Hecht, H. J., Schomburg, D., and Schmid, R. D. 1991. Effects of carbohydrate depletion on the structure, stability and activity of glucose oxidase from Aspergillus niger. Biochim. Biophys. Acta. 1080:138-142.

9. Kim, K. K., Fravel, D. R., and Papavizas, G. C. 1988. Identification of a metabolite produced by Talaromyces dahliae. Phytopathology 78:488-492.

10. Kim, K. K., Fravel, D. R., and Papavizas, G. C. 1990. Production, purification, and properties of a glucose oxidase from the biocontrol fungus Talaromyces flavus. Can. J. Microbiol. 36:199-205.

11. Kim, K. K., Fravel, D. R., and Papavizas, G. C. 1990. Glucose oxidase as the antifungal principle of talaron from Talaromyces flavus. Can. J. Microbiol. 36:760-764.

12. Laemmli, U. K. 1970. Cleavage of structural proteins during the assembly of the head of bacteriophage T4. Nature (Lond.) 227:680-685.

13. Marois, J. J., Johnston, S. A., Dunn, M. T., and Papavizas, G. C. 1982. Biological control of Verticillium wilt of eggplant. Plant Dis. 66:1166-1181.

14. Mischak, H., Kubicek, C. P., and Röhr, M. 1985. Formation and location of glucose oxidase in citric acid producing mycelia of Aspergillus niger. Appl. Microbiol. Biotechnol. 21:27-31.

15. Mizuno, K., Yagi, A., Takada, M., Matsuura, K., Yamaguchi, K., and Asano, K. 1974. A new antibiotic, talaron. J. Antibiot. 27:560-563.

16. Roland, J. C., and Vian, B. 1991. General preparation and staining of thin sections. Pages 1-66 in: Electron Microscopy of Plant Cells. J. L. Hall and C. Hawes, eds. Academic Press, London.

17. Rovira, A. D. 1969. Plant Exudates. Bot. Rev. 35:35-57.

18. Sambrook, J., Fritsch, E. F., and Maniatis, T. 1989. Molecular Cloning, A Laboratory Manual. 2nd ed. Cold Spring Harbor Press, Cold Spring Harbor, NY.

19. Shirling, E. B., and Gottlieb, D. 1966. Methods for characterization of Streptomyces species. Int. J. Syst. Bacteriol. 16:313-340.

20. Stosz, S. K., Fravel, D. R., and Roberts, D. P. 1996. In vitro analysis of the role of glucose oxidase from Talaromyces flavus in biocontrol of the plant pathogen Verticillium dahliae. Appl. Environ. Microbiol. 62:3183-3186.

21. Takegawa, K., Fujiwara, K., Iwahara, S., Yamamoto, K., and Tochikura, T. 1989. Effect of deglycosylation on N-linked sugar chains on glucose oxidase from Aspergillus niger. Biochem. Cell. Biol. 67:460-464.

22. Towbin, H., Staehhelin, T., and Gordon, J. 1979. Electrophoretic transfer of proteins from polyacrylamide gels to nitrocellulose sheets: Procedure and some applications. Proc. Natl. Acad. Sci. U.S.A. 76:4350-4354.

23. Van Dijken, J. P., and Veenhuis, M. 1980. Cytochemical localization of glucose oxidase in peroxisomes of Aspergillus niger. Eur. J. Appl. Microbiol. Biotechnol. 9:275-283.

24. Zetelaki, K., and Vas, K. 1968. The role of aeration and agitation in the production of glucose oxidase in submerged culture. Biotechnol. Bioeng. $10: 45-59$. 